\title{
Homeless population and COVID-19
}

\author{
Bruno Eduardo Freitas Honorato 1 \\ Ana Carolina S. Oliveira ${ }^{2}$ \\ 1 Universidade Federal de Alfenas / Instituto de Ciências Sociais Aplicadas, Varginha / MG - Brazil \\ 2 Instituto Federal de Ciência e Tecnologia do Sul de Minas Gerais, Inconfidentes / MG - Brazil
}

\begin{abstract}
The objective of this work is to propose practical strategies to support the homeless population during the COVID-19 pandemic in Brazil. It adopts qualitative research, based on interviews with professionals in the field, analysis of information collected on a national news online portal, and analysis of articles, research reports and information documents from other countries. The findings allow suggesting strategies for local governments, particularly regarding social assistance and equipment to support homeless people in Brazil. The results, although partial, include a comparative panorama that allows strategies that are unprecedented in Brazil. We also highlight some issues that need to be considered by the federal, state, and local governments in view of the urgency posed by the COVID-19 pandemic.
\end{abstract}

Keywords: COVID-19; homeless population; social assistance.

\section{População em situação de rua e COVID-19}

O objetivo deste trabalho é propor sugestões práticas para a atuação no atendimento à população em situação de rua diante da pandemia da COVID-19 no Brasil. Com base numa pesquisa qualitativa contendo entrevistas com profissionais da área, análise de informações levantadas num portal de notícias de amplitude nacional e levantamento de artigos, relatórios de pesquisa e documentos informativos de outros países, sugerimos algumas estratégias que podem contribuir para a atuação da gestão municipal, sobretudo no âmbito da assistência social e nos equipamentos de assistência às pessoas em situação de rua no Brasil. Nossos resultados são parciais, embora incluam um panorama comparativo que permite inclusão de estratégias, ao que parece, ainda não implementadas no país. Destacamos também algumas questões que precisam ser repensadas pelos governos federal, estadual e municipal diante da urgência da implementação de políticas durante a pandemia da COVID-19.

Palavras-chave: COVID-19; população em situação de rua; assistência social.

\section{Población en situación de calle y COVID-19}

El objetivo de este trabajo es proponer sugerencias prácticas para actuar en la asistencia a la población sin hogar que frente a la pandemia de COVID-19 en Brasil. Con base en una investigación cualitativa que contiene entrevistas con profesionales del área; análisis de información extraída de un portal nacional de noticias; y recopilación de artículos, informes de investigación y documentos de información de otros países; sugerimos algunas estrategias que pueden contribuir al desempeño de la gestión municipal, especialmente en el ámbito de la asistencia social y en el equipamiento de asistencia para las personas que viven en las calles en Brasil. Nuestros resultados son parciales, aunque incluyan un panorama comparativo que permite la inclusión de estrategias que, al parecer, aún no se han implementado en Brasil. También destacamos algunos problemas que los gobiernos federales, estatales y municipales deben repensar en vista de la urgencia de implementar políticas durante la pandemia de COVID-19.

Palabras clave: COVID-19; población sin hogar; asistencia social. 


\section{INTRODUCTION}

During challenging times, when we must be isolated in our homes, the concern for those who have nowhere to live comes to the fore. Building social policies for people experiencing homelessness (hereinafter PEH) has always been a challenge in Brazil, and this has been previously addressed from different perspectives (Honorato, 2014; Honorato \& Saraiva, 2016; Honorato \& Saraiva, 2017; Honorato, Saraiva, \& Silva, 2017). However, the current picture is urgent, and the changes provoked by the new coronavirus (COVID-19) in the global arena demand quick and increasingly effective responses to stabilize the scenario, especially the initiatives targeted at population groups with a higher risk of contamination.

Identified in December 2019 in the city of Wuhan, China, the new coronavirus, called SARS-CoV-2, can infect people of any age and is especially threatening for the older people and individuals with chronic diseases (World Health Organization, 2020). Indeed, the disease's serious complications and the increasing number of deaths around the world have created global concern about the geographical advance of the virus.

PEH deserve special consideration, as this population is naturally susceptible to infection and at higher risk of exposure, due to their precarious living conditions (Aguiar, Meireles, Rebelo, \& Barros, 2020). Homelessness leads to great social vulnerability, and in the specific case of Brazil, to difficulties in accessing the public health system (Hino, Santos, \& Rosa, 2018) and social support (Aguiar et al., 2020). If we consider the high susceptibility to symptomatic infections, hospitalization, and fatality among members of this population group, not only due to old age, but also their accelerated physical decline and mental disorders often resulting from exposure to risks and aggressive elements (Culhane, Treglia, Steif, Kuhn, \& Byrne, 2020), the spread of coronavirus among PEH indicates a worrying trend, with significant implications for public health and health care resources, as even the mildest cases of coronavirus among this population group require isolation and recovery sites (Baggett, Lewis, \& Gaeta, 2020).

Mortality from all causes is five to ten times higher among homeless people younger than 65 when compared to the general population (Baggett et al., 2013) and the COVID-19 infection may increase this disparity (Tsai \& Wilson, 2020). To provide a brief overview of what the PEH contamination index may be, a recent survey by Baggett et al. (2020) estimated the cumulative frequency of 46.3 COVID-19 cases (95\% confidence interval 39, 9-53, 3 cases) per 1,000 people, on April 3, 2020, during a 15-day observation period with a sample of 182 adults.

Compared with the domiciled population, during the same period, Massachusetts had a cumulative frequency of 1.9 cases per 1,000 people, and on April 2, 2020, Boston recorded a cumulative frequency of 1.8 cases per 1,000 people. The international $\mathrm{PEH}$ scenario is alarming, to say the least (Lima et al., 2020).

More than 10 years after the publication of the National Policy for the Homeless Population (Decree No. 7,053/2009), the already precarious living conditions of this social group in Brazil has worsened, particularly since 2017 , as a result of the economic and political crisis the country has faced, the growing unemployment, which has forced families to migrate in search of work, as well as other factors that previously affected these individuals, such as drug addiction, family conflicts, among others. The moment for the implementation of public policies for this population has remained 
a challenge in Brazil (Hino et al., 2018). The last census survey performed between 2007 and 2008 identified a contingent of 31,922 homeless adults (Pesquisa Nacional, 2008).

There are more than 119,636 homeless families registered in the Federal Government's Single Registry for Social Programs (Cortizo, 2019). The precarious reality of homelessness and the high possibility of contamination by COVID-19 urges us to act and outline possible responses to the challenge of addressing PEH during the pandemic. This article proposes practical suggestions to assist this specific populational group in the face of the COVID-19 pandemic in Brazil.

This work was organized into three parts, namely methodological aspects, data analysis and discussion, and final remarks, which offer practical guidelines and suggestions for government action with PEH during the COVID-19 pandemic.

\section{METHODOLOGY}

The methodology consists of systematizing practices that may answer the research questions (Mattos, 2006). For the problem that our objective poses, we have outlined the following strategies: (a) interviewing professionals who work in social care units to assist $\mathrm{PEH}$, such as Centro $\mathrm{POP}^{1}$ managers, sheltering institutions managers, and social caregivers; (b) surveying nationwide news articles published in the press relating PEH to COVID-19; (c) surveying notes, research reports, and articles published on strategies for coping with the pandemic targeted at these populations in other countries. Considering the time constraints and the dynamics of the study object, we opted for the strategies that we believe to be the most effective while seeking to balance the possibility of access and data reliability.

\subsection{Data collection}

For strategy (a), we interviewed two professionals who work on the frontline of the area, namely a coordinator of a Centro $\mathrm{POP}^{2}$ in the countryside of the state of Minas Gerais, and a social caregiver from the Federal District. We also interviewed two members of non-governmental organizations (NGOs), in the cities of Uberlândia and Uberaba, in the countryside of Minas Gerais, who deal directly with PEH in sheltering and recovery institutions, for we consider the contribution of these agents relevant to broaden the context of analysis. Some professionals were chosen from the previous contact with the researchers in previous studies, and at a later stage, others were recommended by players connected to PEH social care. Given the time and access constraints to research during the pandemic, agents were contacted online.

For strategy (b), we relied on articles published on the news portal Globo.com, which is currently the most accessed in Brazil (https://www.alexa.com/topsites/countries/BR, retrieved April 16, 2020). Only written articles addressing the Brazilian context were considered, so videos and podcasts were

\footnotetext{
${ }^{1}$ Translator's Note: (Centro de Referência Especializado para Pessoas em Situação de Rua, "Specialized Reference Center for the Homeless Population").

${ }^{2}$ As the coordination of Centro POP is typically occupied by a single person, who could be identified if the city where they operate were mentioned, we chose to omit the name of the municipality, in order to ensure the participant's anonymity. However, it is worth mentioning that it is not the office in any of the other two cities mentioned (Uberlândia and Uberaba).
} 
not included. We adopted combinations of the following keywords in the search, in Portuguese ${ }^{3}$ : coronavírus, moradores de rua, pessoas em situação de rua, prefeitura, estado, governo federal, ONGs, COVID-19 and ações. The search comprised the period between December 12, 2019, and the day of the outbreak in China, on April 7, 2020. However, the news surveyed were more frequent between March 24 and 27. We analyzed 47 news articles ${ }^{4}$ that featured in the title at least two of the keywords mentioned above, combined in the period stipulated for the survey.

For strategy (c), articles, research reports, and editorial notes published in international journals were surveyed, aiming to establish a comparative basis for the actions we propose in other research strategies.

\subsection{Data analysis}

The objective of the interviews conducted in strategy (a) was to create a basis for interpreting the data collected in the other stages, which would bring us closer to practice through contact with professionals dealing directly with $\mathrm{PEH}$ in social care units. For this reason, we did not perform a thorough analysis of linguistic elements, but an examination of the semantic-pragmatic meaning of the conversation instead, as suggested by Mattos (2006), along with a synthesized exposition of the respondents' testimonials with data interpretation. We also sought to identify management practice elements in these social care units, which, due to their proximity to the context of the action, could highlight aspects of human inventiveness and insurgency in the process of implementing government measures.

The data collected by strategies (b) and (c) were analyzed through content analysis (Bardin, 2006), considering the following phases: pre-analysis, by skimming all headlines available on the website until the end of the collection; selection of news articles and defining of the corpus of analysis; general reading of the collected material; data coding for the designing of analysis categories based on the theoretical framework and the information from the interviews; clipping of the material in record units (news paragraphs and headlines); categorization according to the principles of mutual exclusion (between categories), homogeneity (within categories), relevance of the message (non-distortion) and objectivity (understanding and clarity of the category); grouping of registration units into common categories (initial categories); progressive categorization of strategy and action types (final categories); inferences and interpretation based on the framework, interviews and comparative data. The repetition of measures that have been implemented at the local and state levels became evident, so we decided to stop data collection according to the saturation criterion.

In strategy (c), we performed an extensive search for articles that related COVID-19 to homelessness on the Spell, Scielo, and Google Scholar platforms. For this strategy, we decided to track the reliability of the sources of articles and reports published by the COVID-19 index of the Publons platform

\footnotetext{
${ }^{3}$ Translator's Note: the translation of the search queries to English goes as follows: coronavirus, homeless, people experience homelessness, local government, state, federal government, NGOs, COVID-19, and actions.

${ }^{4}$ As the Globo.com portal does not provide the number of articles published in the stipulated period of the survey, it was not possible to measure the exact number of pre-analyzed news articles. However, the total of texts was estimated at 150, among the various keywords.
} 
(https://publons.com/publon/covid-19/?sort_by=date\&title=homeless, retrieved on April 17, 2020), although the urgency of the publications and the restricted search term led us to find reference only to articles by Tsai and Wilson, (2020); Kirby, (2020); Wood, Davies, and Khan (2020). Considering the comparative analysis together with the other data we analyzed in Brazil, we found it plausible to also include the analysis by Aguiar et al. (2020) regarding government strategies in Portugal and the document issued by the Centers for Disease Control and Prevention (CDC), published on April 2, 2020, with guidelines for service providers on how to assist people experiencing homelessness during the COVID-19 pandemic.

\section{DISCUSSION}

As we surveyed news articles relating homelessness to COVID-19, we categorized and analyzed initiatives from 15 states, in more than 30 municipalities, in all regions of the country (Southeast, Northeast, Central-West, North, and South). Box 1 presents these actions and strategies. Later, five types of basic strategies that municipalities and states have adopted were identified as key categories, namely 1) prevention, 2) intervention by the municipalities, 3) awareness, 4) infrastructure and 5) strategies aimed at workers dealing with $\mathrm{PEH}$. We also identified initiatives by state and federal control bodies, such as the State and Federal Public Defender's Office, which were categorized as actions by the judicial branch, to distinguish them from local government strategies.

The actions were grouped by similarity at the local and state levels, although some news highlights actions taken by third-sector organizations, such as NGOs working specifically with PEH. Likewise, we differentiated the actions that are being put in place from those reported as proposals or plans to be executed later by local or state governments. Most news reports on actions under implementation or that have already been executed, thus pointing to an optimistic scenario.

\subsection{Brazil}

The most frequent measure implemented by municipalities and states is the adaptation of existing or temporary shelters, closely followed by the assembly of new temporary shelters for PEH. Therefore, infrastructure strategies stand out as the most frequent. As for prevention and awareness strategies, the collection and distribution of hygiene and food items, as well as guidance on how to prevent the disease stood out as the most frequent actions in the corpus analyzed. To develop the techniques and actions mentioned, the relevance of the articulation between different sectors inside the government - such as seizing cultural, religious, sporting and educational venues to be used as shelter sites - and between government and voluntary initiatives such as NGOs and institutions - reception, preparation and distribution of cleaning and food items, is evident.

Furthermore, it is worth highlighting the diversity of adaptation measures in social care units for $\mathrm{PEH}$, from the simplest ones, such as intensifying the hygiene in the shelters, reducing their capacity, and rearranging the bunk beds, to the most complex, such as screening people who have symptoms or who are at risk, and setting up outpatient clinics. All of these protocols follow the recommendations of the World Health Organization (WHO) and the Brazilian Ministry of Health. 


\section{BOX 1 STRATEGIES AND ACTIONS FOR TACKLING COVID-19 AMONG PEH IN BRAZIL}

\begin{tabular}{|c|c|c|c|}
\hline Strategies & Actions & Scope & Region \\
\hline \multirow{6}{*}{ Prevention } & $\begin{array}{l}\text { Collect and distribute cleaning products and food items } \\
\text { in places of PEH agglomeration }\end{array}$ & $\begin{array}{l}\text { Municipal, state and } \\
\text { volunteer work }\end{array}$ & $\begin{array}{l}\text { Southeast, North, } \\
\text { South, and Northeast }\end{array}$ \\
\hline & Offer free meals at state "popular restaurants" & State & Northeast \\
\hline & Provide surgical facemasks to PEH & Municipal & Southeast \\
\hline & Perform a census survey to count PEH* & Municipal & Southeast \\
\hline & $\begin{array}{l}\text { Identify and map PEH with suspected COVID-19, as } \\
\text { well as possible new suspected cases. }\end{array}$ & Municipal & Southeast \\
\hline & Develop a contingency plan for PEH & Municipal & Southeast \\
\hline \multirow{2}{*}{ Intervention } & $\begin{array}{l}\text { Refer PEH with suspected COVID-19 to health facilities } \\
\text { or call SAMU, and follow such referrals }\end{array}$ & Municipal & $\begin{array}{l}\text { Southeast, Central- } \\
\text { West, and North }\end{array}$ \\
\hline & $\begin{array}{l}\text { Transporting PEH in team vehicles and following } \\
\text { recommendations to avoid contagion }\end{array}$ & Municipal & Southeast \\
\hline \multirow[b]{2}{*}{ Awareness } & $\begin{array}{l}\text { Create information centers about COVID-19 for PEH, } \\
\text { managed by health professionals }\end{array}$ & Municipal & Southeast \\
\hline & $\begin{array}{l}\text { Guide disease, hygiene and prevention, and on shelters } \\
\text { sites in the municipality }\end{array}$ & $\begin{array}{l}\text { Municipal, state and } \\
\text { volunteer work }\end{array}$ & $\begin{array}{l}\text { Southeast, South, } \\
\text { Northeast, and Central- } \\
\text { West }\end{array}$ \\
\hline \multirow{6}{*}{ Infrastructure } & Install basins in crowded areas & Municipal & Southeast \\
\hline & Provide resources for renting rooms in hotels & State & North \\
\hline & $\begin{array}{l}\text { Offer normal or extended assistance to PEH (access to } \\
\text { housing, food, or hygiene) through the city's existing } \\
\text { shelters. }\end{array}$ & $\begin{array}{l}\text { Municipal, state and } \\
\text { volunteer work }\end{array}$ & $\begin{array}{l}\text { Southeast, North, and } \\
\text { Northeast }\end{array}$ \\
\hline & $\begin{array}{l}\text { Install temporary shelters to increase the number of } \\
\text { vacancies in the city }\end{array}$ & Municipal and state & $\begin{array}{l}\text { Southeast, Northeast, } \\
\text { North, and South }\end{array}$ \\
\hline & $\begin{array}{l}\text { Set up or adapt sites exclusively for PEH with risk } \\
\text { factors, with suspected COVID-19 or flu-like symptoms }\end{array}$ & Municipal & Southeast and South \\
\hline & $\begin{array}{l}\text { Adapt shelters and popular restaurants according to } \\
\text { WHO and Ministry of Health recommendations }\end{array}$ & Municipal and state & $\begin{array}{l}\text { Southeast, North, and } \\
\text { Northeast }\end{array}$ \\
\hline \multirow[b]{2}{*}{ Workers } & Guide volunteers who have direct contact with $\mathrm{PEH}$ & Volunteers & Southeast \\
\hline & $\begin{array}{l}\text { Provide hygiene materials and PPE to the technical } \\
\text { team in direct contact with sheltered individuals }\end{array}$ & Municipal & Southeast \\
\hline
\end{tabular}

Notes: * Some of the news articles report about planned actions that have not necessarily been implemented, as is the case with this one, which refers to the possibility of performing a census survey.

Source: Elaborated by the authors.

\footnotetext{
${ }^{5}$ Translator's Note: Popular Restaurants, or "People’s Restaurants", are government-supported restaurants that offer inexpensive meals and are open to all city residents.
} 
The actions shown in Box 1 have been planned and/or implemented in different municipalities and states. However, none of them have implemented all of them so far and most have put in place no more than four of the actions mentioned above.

Measures by other bodies that seek to engage the Executive Branch - such as the Federal and State Public Defender Offices, judges with the Public Treasury courts, and the State Public Prosecutor's Office - were frequently recommended to reinforce protection and assistance to $\mathrm{PEH}$, with or without detailing the actions to be taken, and establish deadlines for the adoption of recommendations. Although there have been cases of omission, many of the initiatives follow the guidelines of these bodies. In some, these documents require an official position by local and state governments concerning PEH.

According to the respondents, most of the initiatives implemented in the municipalities were not official orders issued by the local government, but rather, by the professionals who, working on the front line with PEH, conduct individual research on the adequate measures and care necessary to prevent contamination, prompting the local government to fulfill the specific demands of this population, as well as the provision of extra space for the installation of shelter and isolation sites.

The level of information provided by the federal government - which is nonexistent in the specific case of PEH - and state and local ones, was often questioned by the respondents. No guidance was given by the federal government on care and action strategies targeted at that population, despite the manifest risk of viral contamination and transmission. One of the respondents, who is a member of an NGO in Uberlândia, claimed to have been offered guidance by the local government, but this was the only reference to this matter.

Another respondent reported that the Ministry of Health even offered a prevention course, although not directly targeted at PEH. However, with the higher workload and the reduced staff both due to the need for turnover and removal of professionals with risk factors -, it would have been impossible to take part in it.

In Brasília, the situation seems much more complex than in the countryside, according to the reports we had access to through the interviews. The lack of basic care and the disarticulation between the Federal District social care units have caused emotional distress on the sector's workers, who often need to take initiative on decisions that should be informed in advance. The workers' mental health came up with special force during the interviews with the staff of government-supported social care units but was not mentioned by the NGO members. The negligence of governments towards these professionals is worrying both at the basic level, in terms of providing general guidelines for care and PPE, as well as at the emotional level, as these specialists work in risky environments, facing a lack of workforce due to absenteeism and under pressure to forcefully assist and shelter individuals who had been previously suspended due to aggression, alcoholism, among other reasons.

The disarticulation between social care units also deserves attention. Even in the countryside, the degree of disarticulation between the Psychosocial Care Centers for Alcohol and Other Drugs (Caps $\mathrm{AD}$ ) and the Centro POP directly affects the provision of care. Also, the overall conditions and the level of access that PEH have to the Unified Health System (SUS) concern the respondents, as these individuals are often assisted due to episodes involving alcohol or drug use, which are not considered 
to be the responsibility of SUS, but of the bodies linked to PEH. Even when they have symptoms, $\mathrm{PEH}$ are not always assisted due to episodes involving alcohol or drug use.

Another issue that must be highlighted is the impossibility by many PEH to receive the financial aid of $600 \mathrm{BRL}$ given by the federal government. This happens because even though they are included in the Single Registry (CadÚnico), they need to show their personal documents to receive the benefit, which is often unfeasible. In other words, the federal government has disregarded this peculiarity when planning the granting of this benefit.

\subsection{Brief International Overview}

After a quick survey on tackling COVID-19 among PEH worldwide, we summarized the key strategies identified in four countries, namely England, Australia, Portugal, and the United States.

England has designed a plan, already approved by the government, focused on protecting the vulnerable, reducing virus transmission, and mitigating outbreaks (Kirby, 2020). It has allocated $£ 3.2$ million for initial emergency financing to people who need to be isolated and seeks to empty the PEH social care units by referring them to other isolation facilities, such as vacant hotels (Kirby, 2020).

In turn, Portugal ensures the continuity of care, sheltering and food distribution services to PEH, adopting measures such as establishing quarantine sites, in addition to raising awareness and giving information and instructions about the pandemic for workers in the area, aiming at controlling the spread of the virus in social care units (Aguiar et al., 2020).

Similarly to Brazil, Australia faces challenges that range from the provision of simple hygiene conditions, such as handwashing, to ensuring the possibility of isolation and access to health services and PPE for this population group (Wood et al., 2020). However, despite the obstacles, the country has yet to propose a plan specifically aimed at PEH (Kirby, 2020), and so has the United States (Tsai \& Wilson, 2020).

The authors suggest testing and training for the identification of COVID-19 and initiatives aimed at $\mathrm{PEH}$, as well as alternative sites for the isolation and treatment of this population.

\subsection{Practical Suggestions for Assisting PEH During the COVID-19 Pandemic}

In this section, we present a compendium of practical suggestions to be adopted by local governments and the technical staff dealing with PEH in Brazil. It is based on the analyzed data and strongly inspired by the document published by the Center for Disease Control and Prevention (CDC) which is especially aimed at tackling COVID-19 among PEH - while considering the specifics of the Brazilian case.

The proposals are grouped according to three possible situations: before, during, and after a COVID-19 outbreak among the local homeless population and according to the strategies identified through the corpus analysis. For the current Brazilian scenario, as no COVID-19 outbreak among PEH has been identified, we designed Box 2, which focuses on outlining action plans to prevent outbreaks. Boxes 3 and 4 - during and after the outbreak, respectively - have been adapted from the aforementioned document, with the inclusion of specific categories. 


\section{Prevention strategies}

- Provide preventive supplies to social care units assisting PEH, such as soap, alcohol sanitizers, tissues, disposable cups, and surgical or handmade facemasks.

- Establish ongoing communication with your local public health department and social care units assisting PEH to facilitate access to relevant information before and during an outbreak.

- Have an emergency plan in place to help reduce the impact of the outbreak. During your planning process, allow homeless service providers and PEH to collaborate and share information.

- Build strong alliances before an outbreak, so as to provide organizations with the support and resources needed to respond effectively.

- Provide a list of key contacts at your local and state health departments to social care units.

- Include contingency plans to cope with increased absenteeism. Consider hiring temporary employees in the event of an outbreak.

- Promote the practice of everyday preventive actions. Use health messages and materials developed by credible public health sources, such as your local and state public health departments.

- Identify PEH who are at high risk for COVID-19 complications (those who are older or have underlying health conditions) to ensure that their specific needs are considered.

- Plan for higher shelter usage during the outbreak.

- Address the key prevention strategies in your emergency operations plan. Review and update it regularly.

\section{Intervention strategies}

- Transport PEH in vehicles owned by the social care units and follow the recommendations to avoid contagion.

- Social care units must be prepared to report cases of respiratory illness to their local health department and to transport patients with serious illnesses to medical facilities. Monitor such referrals.

\section{Awareness strategies}

- Communicate about COVID-19 and everyday preventive actions.

- Create a communication plan for distributing timely and accurate information during an outbreak.

- Identify and address potential language, cultural, and disability barriers associated with communicating COVID-19 information to workers, volunteers, and those you serve.

- Help counter stigma and discrimination in your community. Speak out against negative behaviors and engage with stigmatized groups.

- Share your plans with staff, volunteers, and key community partners and stakeholders and solicit feedback on your plans. 


\section{Infrastructure strategies}

- Adapt sheltering sites and popular restaurants according to the recommendations of the WHO and the Ministry of Health.

- If possible, install handwash basins in crowded areas.

- Keep the normal or extended assistance to PEH (access to housing, food, or hygiene) through the city's existing shelters.

- Identify space that can be used to accommodate PEH with mild respiratory symptoms and separate them from others.

- Make resources available for emergency actions, such as the installation of temporary shelters.

- Consider setting up or adapting specific space aimed exclusively at PEH with suspected COVID-19 or flu-like symptoms and, if possible, at those at high risk.

\section{Support strategies for workers}

- Provide PPE for COVID-19 to the staff working in direct contact with PEH.

- Develop training and educational materials about the plans for staff and volunteers.

- Provide services that ensure the mental health of all workers. This is extremely important for the effectiveness of the service.

Source: Elaborated by the authors.

\section{BOX 3}

\section{ACTION PLAN SUGGESTIONS TO TACKLE COVID-19 DURING AN OUTBREAK}

\section{Prevention strategies}

- If cases are reported in your community, put your emergency plan into place to protect clients, workers, and visitors.

- Stay updated about the local scenario. Stay updated on the local level of transmission of COVID-19 through your local and state health departments.

- Implement everyday preventive actions and provide instructions to your workers about actions to prevent disease spread. Meet with your staff to discuss plans to help clients implement personal preventive measures.

- Staff and volunteers at high risk of severe COVID-19 (those who are older or have underlying health conditions) should not be designated as caregivers for sick clients who are staying in the shelter.

- If staff are handling client belongings, they should use disposable gloves. Make sure to train any staff using gloves to ensure proper use.

- At check-in, provide any client with respiratory symptoms (cough, fever) with a surgical mask.

- Monitor clients who could be at high risk for complications from COVID-19 (those who are older or have underlying health conditions) and reach out to them regularly.

- Consider reducing the cleaning frequency of bedrooms and bathrooms dedicated to sick clients to as-needed cleaning, so as to avoid unnecessary interaction with them.

- If you identify any client with severe symptoms, arrange for them to receive immediate medical care. 


\section{Awareness strategies}

- Keep staff and clients up-to-date on the recommendations by public health officials, as well as changes in procedures that may be related to the outbreak.

- Post signs at entrances and in strategic places providing instruction on handwashing, breathing, and cough etiquette.

\section{Infrastructure strategies}

- Minimize the number of staff members who have face-to-face interactions with clients with respiratory symptoms.

- Use physical barriers to protect staff who will have interactions with clients with unknown infection status.

- Limit visitors to the facility.

- In general sleeping areas (for those who are not experiencing respiratory symptoms), ensure that beds/mats are far apart, and request that all clients sleep head-to-toe.

- Provide access to fluids, tissues, plastic bags for the proper disposal of used tissues.

- Ensure bathrooms and other sinks are consistently stocked with soap and drying materials for handwashing. Provide alcohol-based hand sanitizers that contain at least $70 \%$ alcohol (if that is an option at your shelter) at key points within the facility, including registration desks, entrances/exits, and eating areas.

- Prioritize clients with mild respiratory symptoms for individual rooms, if possible, and have them avoid common areas.

- If individual rooms for sick clients are not available, consider using a large, well-ventilated room.

- In areas where clients with respiratory illness are staying, keep beds at least 6 feet apart, use temporary barriers between beds (such as curtains), and request that all clients sleep head-to-toe.

- If possible, designate a separate bathroom for sick clients with COVID-19 symptoms.

- Ensure that all common areas within the facility adhere to good cleaning practices.

\section{Support strategies for workers}

- Encourage sick workers and volunteers to stay at home (or to go home if they experience symptoms while they are in the unit) to protect other people from infection.

- Provide services that ensure the physical and mental health of all workers. This is extremely important for the effectiveness of the service.

Source: Adapted from Interim Guidance for Homeless Service Providers (2020). 
Follow-up strategies

- Remember, a COVID-19 outbreak could last a long time, and the impact on your facility may be considerable.

- Take some time to talk about your experiences with managers, staff, and clients.

- Evaluate the effectiveness of your organization's plan of action.

- Discuss and note the lessons learned. Were your COVID-19 preparedness actions effective at your organization? Talk about problems found in your plan and effective solutions.

- Participate in community discussions about emergency planning. Let others know about what readiness actions worked. Maintain communication lines with your community (e.g., social media and email lists).

- Continue to practice everyday preventive actions.

- Maintain and expand your emergency planning. Look for ways to expand community partnerships. Identify agencies or partners needed to help you prepare for an infectious disease outbreak in the future.

Source: Adapted from Interim Guidance for Homeless Service Providers (2020).

\section{CONCLUSION}

This article aimed to propose practical suggestions for tackling COVID-19 among PEH in Brazil. For this, we opted for a qualitative approach based on interviews with professionals in the field, the analysis of information collected in a national news portal, and a survey of articles, research reports, and information documents issued by other countries. We summarized these suggestions in Boxes 2 , 3 , and 4 and by doing so, we hope to contribute to the performance of local governments and social care units assisting PEH in the country.

In addition to the suggestions, this study has raised some questions that need to be addressed by governments at the federal, state, and local levels. Based on our data, we reiterate these issues in the final remarks:

1. The Brazilian federal government has yet to comment on the creation and implementation of emergency policies to support social care agencies in tackling COVID-19 among PEH. We believe this position is negligent towards this specific social group, to say the least.

2. Most of the initiatives undertaken by the cities have not been officially ordered by the local governments, but by the very professionals working in social care institutions and NGOs assisting $\mathrm{PEH}$. We believe that initiatives by the federal government and stricter demands by the judicial branch can lead local governments to act, as they have yet to take a clear position regarding $\mathrm{PEH}$ in their municipalities.

3. With the higher workload, the reduced staff due to absenteeism, the disarticulation between social care units and NGOs, lack of PPE in several units, and forced to make decisions and undertake initiatives to tackle COVID- 19 without official support from the local, state and federal governments, social workers are often overburdened, which can compromise their physical and mental health, in addition to reducing the number of available workers. Therefore, we firmly 
believe that these workers need immediate support from the government to mitigate each of the deficiencies mentioned above.

4. The impossibility of many PEHs to receive the $600 \mathrm{BRL}$ financial aid given by the federal government exposes a flaw in the implementation of this policy, which needs to be reviewed in time, so as to provide better assistance for $\mathrm{PEH}$ in the face of the emergency.

Finally, this study has some limitations, namely the lack of interviews with other frontline professionals, working in a wider variety of municipalities in the country, as well as a lack of more input from other countries. These, therefore, configure possibilities for future research. Based on the testimonials collected, we argue, above all, on the gaps that need to be filled in the enforcement of emergency policies, hoping that these can be remedied soon through a consistent review.

Although there have been advances in the access and production of PEH care in SUS, the precariousness of the access and the violation of health rights of this population have been constantly reported by researchers in the area (Paula \& Laura, 2018). The Brazilian PEH need, particularly during this pandemic, not only plans but the effective implementation of coping strategies. 


\section{REFERENCES}

Aguiar, A., Meireles, P., Rebelo, R., \& Barros, H. (2020). Covid-19 e as pessoas em situação de sem-abrigo: ninguém pode ser deixado para trás. In M. Tavares \& C. Silva (Orgs.), Da emergência de um novo vírus humano à disseminação global de uma nova doença: doença por coronavírus 2019 (Covid-19). (Capítulo IX, pp. 1-6). Porto, Portugal: Universitário de São João; Universidade do Porto. Retrieved from http://asset.youoncdn. com/ab296ab30c207ac641882479782c6c34/7c7 b39d50c8250c4b32f991c3245e5f7.pdf

Baggett, T. P., Hwang, S. W., O'Connell, J. J., Porneala, B. C., Stringfellow, E. J., Orav, E. J., ... Rigotti, N. A. (2013). Mortality among homeless adults in Boston: shifts in causes of death over a 15 -year period. JAMA internal medicine, 173(3), 189-195.

Baggett, T. P., Lewis, E., \& Gaeta, J. M. (2020). COVID-19 outbreak at a large homeless shelter in Boston: Implications for universal testing. medRxiv, Preprint. Retrieved from https://www.medrxiv.org/ content/early/2020/04/15/2020.04.12.20059618

Bardin, L. (2006). Análise de conteúdo. Lisboa, Portugal: Edições 70. (Obra original publicada em 1977).

Cortizo, R. M. (2019). População em situação de rua no Brasil: o que os dados revelam? Brasília, DF: Ministério de Cidadania.

Culhane, D., Treglia, D., Steif, K., Kuhn, R., \& Byrne, T. (2020). Estimated Emergency and Observational/ Quarantine Capacity Need for the US Homeless Population Related to Covid-19 Exposure by County; Projected Hospitalizations, Intensive Care Units and Mortality. Los Angeles, CA: UCLA Campuswide Homelessness Initiative. Retrieved from: https:// escholarship.org/uc/item/9g0992bm

Decreto No 7.053 de 23 de dezembro de 2009. (2009). Institui a Política Nacional para a População em Situação de Rua e seu Comitê Intersetorial de Acompanhamento e Monitoramento, e dá outras providências. Brasília, DF: Presidência da República.

Hino, P., Santos, J. O., \& Rosa, A. S. (2018). Pessoas que vivenciam situação de rua sob o olhar da saúde. Revista Brasileira de Enfermagem, 71(supl1), 732-740.
Honorato, B. E. F. (2014). Ordem e subversão nas cidades: Um estudo sobre a população em situação de rua de Belo Horizonte (Master Thesis). Universidade Federal de Minas Gerais, Minas Gerais, Belo Horizonte.

Honorato, B. E. F., \& Saraiva, L. A. S. (2016). Cidade, População em Situação de Rua e Estudos Organizacionais. Desenvolvimento em Questão, 14(36), 158-186.

Honorato, B. E. F., \& Saraiva, L. A. S. (2017). Quando a Casa é a Marquise, o Albergue, a Rua: discursos e políticas sociais para pessoas em situação de rua em Belo Horizonte. Administração Pública e Gestão Social, 9(4), 244-309.

Honorato, B. E.; Saraiva, L. A. S., \& Silva, E. R. (2017). A construção social da ordem e da subversão nos discursos da (e sobre a) população em situação de rua de Belo Horizonte. Revista Organizações em Contexto, 13(26), 339-383.

Interim Guidance for Homeless Service Providers. (2020, March 25). Centers for Disease Control and Prevention. Departament of Health \& Human Services. Retrieved from https://www.cdc.gov/ coronavirus/2019-ncov/communication/guidancelist.html?Sort=Date\%3A\%3Adesc

Kirby, T. (2020, March 26). Efforts escalate to protect homeless people from COVID-19 in UK. The Lancet Respiratory Medicine. Retrieved from https://www. thelancet.com/journals/lanres/article/PIIS22132600(20)30160-0/fulltext\#articleInformation

Lima, N. N. R., Souza, R. I., Feitosa, P. W. G., Moreira, J. L. S., Silva, C. G. L., \& Neto, M. L. R. (2020). People experiencing homelessness: Their potential exposure to COVID-19. Psychiatry Research, 288, 112945.

Mattos, P. L. C. L. (2006). Análise de entrevistas não estruturadas: da formalização à pragmática da linguagem. In A. Silva, C. Godoi, \& R. Bandeirade-Mello (Orgs.), Pesquisa qualitativa em estudos organizacionais: paradigmas, estratégias e métodos (pp. 347-373). São Paulo, SP: Saraiva.

Paula, M. D. S., \& Laura, C. M. F. (2018, January). População em situação de rua: seus (des) encontros com a saúde, construção de visibilidades, protagonismo e possibilidades de garantia de direitos sociais. In Proceedings of 2018 Convención Internacional de Salud, Havana, Cuba. Retrieved from: http://www.convencionsalud2018. 
sld.cu/index.php/connvencionsalud/2018/paper/ view/1805/818

Pesquisa Nacional sobre a População em Situação de Rua. (2008). Sumário Executivo. Brasília, DF: Ministério do Desenvolvimento Social e Combate à Fome.

Tsai, J., \& Wilson, M. (2020). Covid-19: a potential public health problem for homeless populations. The Lancet Public Health, 5(4), e186-e187.
Wood, L., Davies, A., \& Khan, Z. (2020). Covid-19 precautions-easier said than done when patients are homeless. The Medical Journal of Australia, Preprint.

World Health Organization. (2020, January 05). Pneumonia of unknown cause - China. (Disease outbreak News). Retrieved from https://www. who.int/csr/don/05-january-2020-pneumonia-ofunkown-cause-china/en/

\section{Bruno Eduardo Freitas Honorato}

https://orcid.org/0000-0003-3670-0095

Ph.D. in Administration from the Federal University of Minas Gerais (UFMG); Adjunct Professor at the Institute of Applied Social Sciences at the Federal University of Alfenas (Unifal-MG). E-mail: brunoefh@gmail.com

\section{Ana Carolina S. Oliveira}

https://orcid.org/0000-0003-0081-3741

Master of Science in Administration from the Federal University of Minas Gerais (UFMG); EBTT Professor at the Federal Institute of Education, Science and Technology of the South of Minas Gerais (IF Sul de Minas). E-mail: carolina.oliveira@ifsuldeminas.edu.br 